\title{
Path Analysis on the Biological and Social Economic Determinants of Neonatal Death in Bantul District, Yogyakarta
}

\author{
Funik Rahma Mei Listiani'), Harsono Salimo²), Bhisma Murti' \\ 1)Masters Program in Public Health, Universitas Sebelas Maret \\ ${ }^{2)}$ Department of Pediatrics, Dr. Moewardi Hospital, Surakarta
}

\begin{abstract}
Background: Nearly four million or two-thirds of the newborns (first week of life) die each year worldwide. In Indonesia, neonatal mortality contributes to $59 \%$ infant mortality. Factors associated with infant death have been reported to be biological and social economic. This study aimed to examine the biological and social economic determinants of neonatal death in Bantul District, Yogyakarta, Indonesia.

Subjects and Method: This was an analytic observational study with a case-control design. Population in this study was all neonates in Panembahan Senopati Hospital who were born from January 2017 to January 2018. A total sample of 200 neonates was selected for this study by fixed disease sampling, consisting of 50 dead and 150 alive neonates. The dependent variable was neonatal death. The independent variables were low birth-weight, asphyxia, prematurity, pregnancy infection, maternal age, maternal education, maternal employment status, and family income. The data were collected by questionnaire and analyzed by path analysis.

Results: Risk of neonatal death directly increased with asphyxia ( $b=3.65 ; 95 \% \mathrm{CI}=1.77$ to 5.52 ; $\mathrm{p}<0.001)$, prematurity $(\mathrm{b}=2.78 ; 95 \% \mathrm{CI}=1.64$ to $3.92 ; \mathrm{p}<0.001)$, and pregnancy infection $(\mathrm{b}=3.04$; $95 \% \mathrm{CI}=1.82$ to 4.26 ; $\mathrm{p}<0.001$ ). Risk of neonatal death was indirectly associated with maternal aged 20-35 years, family income, maternal education, and maternal work outside the house.

Conclusion: The risk of neonatal death directly increases with asphyxia, prematurity, low birth weight, infection. Risk of neonatal death is indirectly associated with maternal aged 20-35 years, family income, maternal education, and maternal work outside the house.
\end{abstract}

Keywords: neonatal death, risk factors, biologycal factor, social and economic factor

Correspondence:

Funik Rahma Mei Listiani, Masters Program in Public Health, Universitas Sebelas Maret, Jl. Ir. Sutami 36 A, Surakarta, Central Java 57126. Email: funikrahmameilistiani@gmail.com.

\section{BACKGROUND}

An indicator of health status in a country is the infant mortality rate. Nearly four million or two-thirds of the newborns (first week of life) worldwide die each year. Lowincome countries contribute $98 \%$ neonatal mortality worldwide (Kaboré et al., 2016). The proposed Sustainable Development Goals (SDGs) target for child mortality aims to end, by 2030, preventable deaths of newborns and children under five. All countries aim to reduce neonatal mortality to as low as 12 deaths per 1,000 live births and under-five mortality to as low as 25 deaths per 1,00o live births (UN-IGME, 2015).

Attention should be paid to decrease neonatal mortality rate (0-28 days) in Indonesia because neonatal mortality contributes to $59 \%$ infant mortality. The neonatal mortality rate in Indonesia was 20 per 1 , 000 live births in 2002, declining to 19 live births in 2007, and settling at the same rate in 2012 (Indonesian Health Ministry, 2015).

Infant mortality rate has been reported to be associated with biological and social economic factors. According to 
Halim et al. (2016), biological factors of infants mortality included asphyxia (43\%), infection (29.3\%), and prematurity (22.2\%). Titaley et al. (2008) stated that low birth weight increased the risk of neonatal death. The maternal factors associated with neonatal death included maternal age $\geq 35$ years and multiparous mother. Social economic factors affecting neonatal death included maternal education, maternal employment status, and family income (Malqvist, 2011; Titaley et al, 2008).

The infant mortality rate (IMR) in Yogyakarta was not able to reach the targeted Millennium Development Goals (MDGs) level. IMR in Yogyakarta in 2012 was 25 per 1,00o live births. The number of neonatal death in Yogyakarta in 2016 was 192 cases. Bantul district was one of the districts in Yogyakarta with the highest neonatal death (61 cases) (Health office of Yogyakarta Province, 2017).

This study aimed to examine the biological and social economic determinants of neonatal death in Bantul District, Yogyakarta, Indonesia.

\section{SUBJECTS AND METHOD \\ 1. Study design \\ This was an analytic observational study with case control design. The study was conducted at Panembahan Senopati Hospi- tal, Bantul, Yogyakarta.}

\section{Population and sample}

The accessible population in this study was all neonates at Panembahan Senopati Hospital, from January 2016 to January 2017. A total sample of 200 neonates was selected for this study by fixed disease sampling, consisting of 50 dead and 150 alive neonates.

\section{Study variables}

The dependent variable was neonatal death. The independent variables were asphyxia, low birthweight, prematurity, infection during pregnancy, maternal age, maternal education, maternal employment status, and family income.

\section{Operational definition of variables}

Neonatal death was defined as infant mortality from 0-28 days of birth. The data of neonatal death were collected from the medical record.

Asphyxia was defined as a condition in which the baby can not breathe immediately, spontaneously, and regularly after birth. The data were collected from the medical record.

Low birthweight was defined as infant weight less than 2,500 g just after birth delivery. The data were collected from the medical record. The measurement scale was continuous (gram).

Prematurity was defined as an infant born at $<37$ week gestation age counted from the first day of the last menstrual period. The data were collected from the medical record.

Infection was defined as a severe infection that occurred in the first month after birth. Neonatal infection consists of congenital syphilis, neonatal sepsis, meningitis, pneumonia, and tetanus neonatorum. The data were collected from the medical record.

Maternal age was defined as the length of time the study subject had lived from birth to the time of the study. Data on maternal age were collected by questionnaire. Measurement scale was continuous, but for the purpose of data analysis it was transformed into dichotomous coded o for age $<35$ years and 1 for age $\geq 35$ years.

Maternal education was defined as the highest formal education attained by the mother. The data were collected by questionnaire. The measurement scale was categorical. 
Maternal employment status was defined as maternal job status. The data were collected by questionnaire. The measurement scale was categorical coded o for working at home and 1 for working outside the house.

Family income was defined as the average family income (Rupiah) received per month for the last six months. The data were collected by questionnaire. The measurement scale was continuous, but for the purpose of data analysis it was transformed into dichotomous coded o for $<$ minimum regional wage and 1 for $\geq$ minimum regional wage.

\section{Data analysis}

The data were analyzed by path analysis to determine the direct and indirect effects.
Path analysis proceeded in 5 steps: (1) model specification, (2) model identification, (3) model fit, (4) parameter estimate, and (5) model respecification.

\section{Research ethics}

The research ethics clearance was obtained from the Research Ethics Committe at Dr. Moewardi Hospital, Surakarta, Indonesia. Research ethics included informed consent, anonymity, and confidentiality.

\section{RESULTS}

\section{Sample Characteristics}

Most infants in this study were male (55\%), normal birthweight (69.5\%). Some infants experienced asphyxia (49.5\%), aterm (74\%), and did not have an infection (78.5\%).

Table 1. Characteristics of the study subjects

\begin{tabular}{|c|c|c|c|}
\hline Characteristic & Category & $\mathbf{n}$ & $\%$ \\
\hline \multirow[t]{2}{*}{ Sex } & Male & 110 & 55.0 \\
\hline & Female & 90 & 45.0 \\
\hline \multirow[t]{2}{*}{ Asphyxia } & Did not experience asphyxia & 101 & 50.5 \\
\hline & Experienced asphyxia & 99 & 49.5 \\
\hline \multirow[t]{2}{*}{ Birthweight } & Normal birthweight $(\geq 2,500 \mathrm{~g})$ & 139 & 69.5 \\
\hline & Low birthweight $(<2,500 \mathrm{~g})$ & 61 & 30.5 \\
\hline \multirow[t]{2}{*}{ Gestational age } & Aterm & 148 & 74.0 \\
\hline & Premature & 52 & 26.0 \\
\hline \multirow[t]{2}{*}{ Infection } & Not infected & 157 & 78.5 \\
\hline & Had an infection & 43 & 21.5 \\
\hline \multirow[t]{2}{*}{ Maternal age } & $<20$ or $\geq 35$ years & 46 & 23.0 \\
\hline & 20-35 years & 154 & 77.0 \\
\hline \multirow[t]{2}{*}{ Birth spacing } & $<2$ years & 77 & 38.5 \\
\hline & $\geq 2$ years & 123 & 61.5 \\
\hline \multirow[t]{2}{*}{ Parity } & 1 or $\geq 3$ & 87 & 43.5 \\
\hline & $2-3$ & 113 & 56.5 \\
\hline \multirow{2}{*}{ Maternal education } & $<$ Senior high school & 76 & 38.0 \\
\hline & $\geq$ Senior high school & 124 & 62.0 \\
\hline \multirow[t]{2}{*}{ Maternal employment } & Working at home & 117 & 58.5 \\
\hline & Working outside the house & 83 & 41.5 \\
\hline \multirow[t]{2}{*}{ Family income (monthly) } & $<$ Minimum regional wage (Rupiah) & 41 & 20.5 \\
\hline & $\geq$ Minimum regional wage (Rupiah) & 159 & 79.5 \\
\hline
\end{tabular}

\section{Path analysis}

Number measured variable $(k)=9$. Number of observation $=(\mathrm{kx}(\mathrm{k}+1)) / 2=45$. Number of estimated parameters $=$ \#number parameter + \#endogenous variable + \#exogenous variable $=12+6+3=21 . \mathrm{Df}=$ \#observation - \#estimated parameters $=45^{-}$ $21=24$ (over estimated). Therefore path analysis could be performed. 


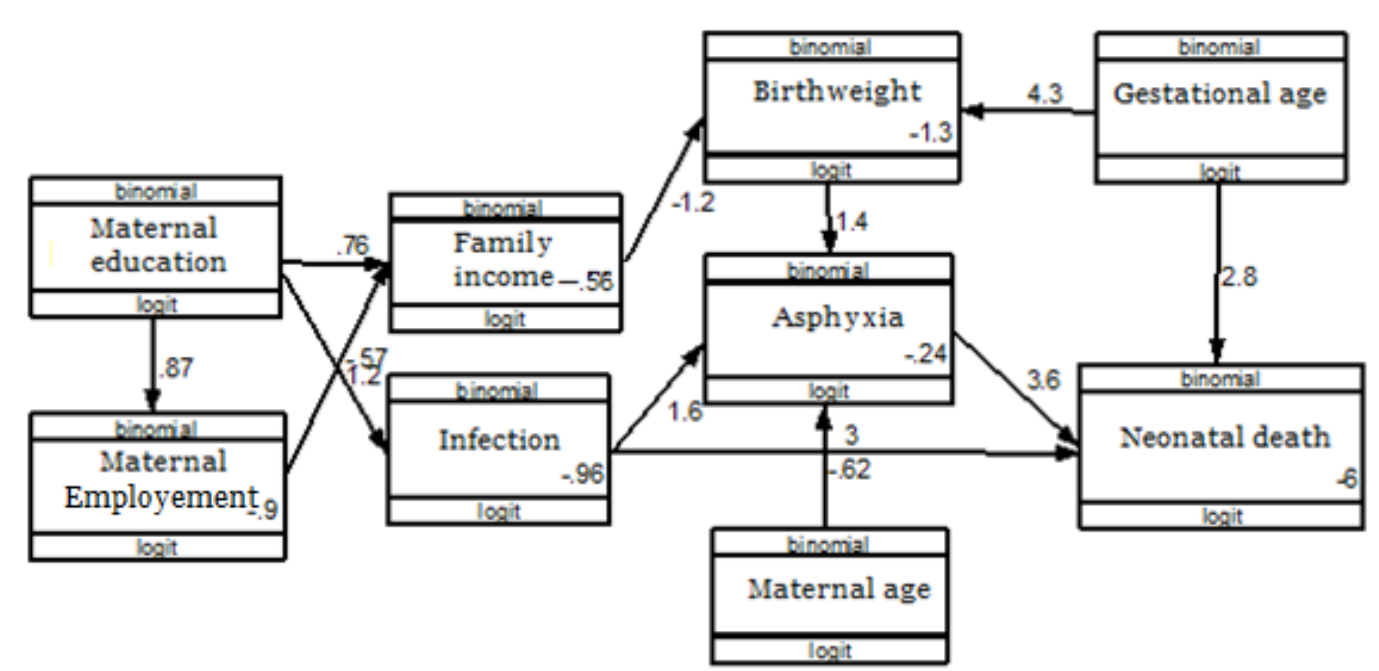

Figure 1. Path diagram with parameter estimates.

Tabel 2. Path analysis on the biological and social economic determinants of neonatal death in Bantul, Yogyakarta

\begin{tabular}{|c|c|c|c|c|c|c|}
\hline \multirow[b]{2}{*}{$\begin{array}{l}\text { Dependent } \\
\text { variable }\end{array}$} & & \multirow[b]{2}{*}{ Independent variable } & \multirow[b]{2}{*}{$\begin{array}{c}\text { Path } \\
\text { coefficient }\end{array}$} & \multicolumn{2}{|c|}{$95 \% \mathrm{CI}$} & \multirow[b]{2}{*}{$\mathbf{p}$} \\
\hline & & & & $\begin{array}{c}\text { Lower } \\
\text { limit }\end{array}$ & $\begin{array}{l}\text { Upper } \\
\text { limit }\end{array}$ & \\
\hline \multicolumn{7}{|l|}{ Direct effect } \\
\hline Neonatal death & $\leftarrow$ & Asphyxia & 3.65 & 1.77 & 5.52 & $<0.001$ \\
\hline Neonatal death & $\leftarrow$ & Prematurity & 2.78 & 1.64 & 3.92 & $<0.001$ \\
\hline Neonatal death & $\leftarrow$ & Infection & 3.04 & 1.82 & 4.26 & $<0.001$ \\
\hline \multicolumn{7}{|l|}{ Indirect effect } \\
\hline Asphyxia & $\leftarrow$ & Low birthweight $<2,500 \mathrm{~g}$ & 1.42 & 0.69 & 2.15 & $<0.001$ \\
\hline Asphyxia & $\leftarrow$ & Infection & 1.62 & 0.71 & 2.53 & 0.001 \\
\hline Asphyxia & $\leftarrow$ & Maternal age 20-35 years & -0.62 & -1.37 & 0.13 & 0.108 \\
\hline Low birthweight & $\leftarrow$ & Prematurity & 4.28 & 3.24 & $5 \cdot 32$ & $<0.001$ \\
\hline Low birthweight & $\leftarrow$ & $\begin{array}{l}\text { Family income } \geq \text { minimum } \\
\text { regional wage }\end{array}$ & -1.22 & -2.27 & -0.18 & 0.022 \\
\hline Infection & $\leftarrow$ & $\begin{array}{l}\text { Maternal education } \geq \text { senior } \\
\text { high school }\end{array}$ & -0.57 & -1.25 & 0.11 & 0.101 \\
\hline $\begin{array}{l}\text { Family income } \\
\geq \text { minimum } \\
\text { regional wage }\end{array}$ & $\leftarrow$ & $\begin{array}{l}\text { Maternal education } \geq \text { senior } \\
\text { high school }\end{array}$ & 0.76 & 0.04 & 1.48 & 0.038 \\
\hline $\begin{array}{l}\text { Family income } \\
\geq \text { minimum } \\
\text { regional wage }\end{array}$ & $\leftarrow$ & $\begin{array}{l}\text { Maternal working outside } \\
\text { the house }\end{array}$ & 1.17 & 0.32 & 2.02 & 0.007 \\
\hline $\begin{array}{l}\text { Maternal working } \\
\text { outside the house }\end{array}$ & $\leftarrow$ & $\begin{array}{l}\text { Maternal education } \geq \text { senior } \\
\text { high school }\end{array}$ & 0.86 & 0.26 & 1.47 & 0.005 \\
\hline Log likelihood & & -553.42 & & & & \\
\hline AIC & & 1142 & & & & \\
\hline BIC & & 1202 & & & & \\
\hline
\end{tabular}

Table 2 showed that the risk of neonatal death directly increased with asphyxia $(b=$ $3.65 ; 95 \% \mathrm{CI}=1.77$ to $5.52 ; \mathrm{p}<0.001)$, prematurity $(\mathrm{b}=2.78 ; 95 \% \mathrm{CI}=1.64$ to 3.92 ; $\mathrm{p}<0.001)$, and infection $(\mathrm{b}=3.04 ; 95 \% \mathrm{CI}=$ 1.82 to $4.26 ; \mathrm{p}<0.001)$.
Asphyxia increased with low birthweight $(b=1.42 ; 95 \% \mathrm{CI}=0.69$ to 2.15 ; $\mathrm{p}<0.001)$, infection $(\mathrm{b}=1.62 ; 95 \% \mathrm{CI}=0.71$ to $2.53 ; \mathrm{p}=0.001$ ), and decreased with maternal aged 20-35 years $(b=-0.62 ; 95 \%$ $\mathrm{CI}=-1.37$ to $0.13 ; \mathrm{p}=0.108$ ). 
Low birthweight increased with prematurity $(b=4.28 ; 95 \% \mathrm{CI}=3.24$ to 5.32 ; $\mathrm{p}<0.001)$ and decreased with family income $\geq$ minimum regional wage $(b=-1.22 ; 95 \%$ $\mathrm{CI}=-227$ to $-0.18 ; \mathrm{p}=0.022$ ).

Infection decreased with higher maternal education $\geq$ senior high school $(\mathrm{b}=$ $0.57 ; 95 \% \mathrm{CI}=-1.25$ to $0.11 ; \mathrm{p}=0.101$ ).

Family income increased with maternal education $\geq$ senior high school $(b=0.76$; 95\% $\mathrm{CI}=0.04$ to $1.48 ; \mathrm{p}=0.038$ ) and maternal working outside the house $(b=1.17 ; 95 \%$ $\mathrm{CI}=0.32$ to 2.02; $\mathrm{p}=0.007$ ).

Maternal education $\geq$ senior high school $(b=0.86 ; 95 \% \mathrm{CI}=0.26$ to $1.47 ; \mathrm{p}=$ 0.005) increased the chance of working outside the house.

\section{DISCUSSION \\ 1. The effect of asphyxia on neonatal death}

This study showed that the neonates with asphyxia had an increased risk of neonatal death. Asphyxia is caused by fetal hypoxia in the uterus. Fetal hypoxia occurs due to impaired exchange and transport of oxygen from mother to fetus, so oxygen supply to the fetus decreases and carbon dioxide levels increase (Pitsawong and Panichkul, 2012). Untreated asphyxia can cause dysfunction of organ system (Lee et al, 2008).

Previous study showed the similar results that asphyxia increased the risk of neonatal death (Lawn et al, 2005; Kabore et al, 2016; Abdullah et al, 2016; Fawole et al, 2011)

The APGAR score system is useful not only for evaluating the clinical status of the infant in the first minute but also as a sign that the infant is in need of resuscitation and evaluates the effectiveness of the treatment (Ehrenstein, 2009). Several studies have demonstrated that low APGAR scores reflect the level of obstetric service availability and inappropriate service standards during delivery (Berglund et al, 2010). Adetola et al. (2011) stated that the accuracy of basic resuscitation can prevent infant mortality by up to 90\% (Adetola et al, 2011).

\section{The effect of prematurity on neonatal death}

This study showed that prematurity increased the risk of neonatal death. Lawn et al. (2005) stated that prematurity ranked third the causes of neonatal death worldwide. According to Flood and Malone (2012), $70 \%$ of the neonatal deaths in developing countries were affected by prematurity. Green and Wilkinson (2012) state that premature infants tend to have low birthweight. A lack of nutrient reserves and immature body systems cause premature infants to be at risk for complications. The risk factors of prematurity were amniotic fluid abnormalities, premature rupture of amniotic membranes, gemelli, chronic hypertension in pregnancy, prematurity of previous pregnancy, maternal age $\geq 35$ years, and cervical incompetence (Derakshi et al, 2014). Deblew et al. (2014) stated that premature babies with an immature body system susceptible to infection and increase the risk of neonatal death.

\section{The effect of infection on the risk of neonatal death}

This study showed that neonatal death increased with infection. This finding is consistent with Lawn et al. (2005), which reported that neonatal death in the world caused by infection. Infection is transmitted from mother to fetus during pregnancy. Mothers with sepsis, premature rupture of amniotic membranes and amniotic fluids disorder increase the risk of infection transmission to the infant (Adetola et al, 2011). Rini (2014) showed that infection is associated with neonatal death. The more 
severe the infection, the greater the risk of infant death.

Maternal infection can be transmitted to the infant in utero and during intrapartum period. Transmission of infection may occur when colonized bacteria from the maternal perineum spread through vagina, amniotic membrane, and amniotic fluids (Chan et al, 2013).

\section{The effect of low birthweight on the risk of neonatal death through asphyxia}

This study showed that asphyxia increased with low birthweight. This finding is consistent with Aslam et al. (2014), Pitsawong et al. (2012), and Nayeri et al. (2012). Low birthweight can be caused by prematurity and intrauterine growth retardation (IUGR) (Prawirohardjo, 2012). Premature infants are had more complex morbidity, including an immature organ system, especially the lungs that led to respiratory failure (Lee et al., 2008). LBW is associated with maternal complication such as gestational hypertension and diabetes (Baker et al., 2006).

\section{The effect of infection on the risk of neonatal death through asphyxia}

This study showed that asphyxia increased with infection. Mother with sepsis during pregnancy and postpartum had potentially life-threatening condition caused by infection (Adetola et al., 2011). Aslam et al. (2014) stated that mother who had sepsis during labor was 10 times more likely to have asphyxia. This finding is consistent with Lee et al., (2008), which stated that mother with a history of infection during pregnancy may transmit infection to their infants and increase the risk of asphyxia.

\section{The effect of maternal age on the risk of neonatal death through asphyxia}

This study showed that mother aged 20-35 years had a lower risk of having infants with asphyxia than a mother aged $<20$ years or $\geq 35$ years. Singh et al. (2013) reported that mother aged $\geq 20$ years have better knowledge about pregnancy and childbirth. They also have a greater responsibility in caring for their babies. Mothers aged <20 years are still growing and the nutrient availability to the fetus may be limited (Lee et al, 2008; Aslam et al, 2014; Pitsawong, 2012; Nayeri et al, 2012). Low birthweight infants have a greater risk of asphyxia because of lungs development is immature (Lee et al., 2008). In addition, psychological of mother aged $<20$ years is still not ready for pregnancy (Ankiyemi et al, 2015).

\section{The effect of prematurity on the risk of neonatal death through low birthweigth}

This study showed that prematurity increased the risk of low birthweight. Muchemi et al. (2015) and Ankiyemi et al. (2015) explained that prematurity was one of the factors associated with low birth weight. Prematurity increased the risk of low birthweight 3.65 times (Muchemi et al., 2015). This finding is consistent with Adetola et al. (2011) which reported that premature infant increased the risk of low birthweigh 7 times than aterm infant.

Green and Wilkinson (2012) stated that premature infant always have low birthweight. Therefore, comprehensive services during labor and postpartum, such as safe delivery, body temperature monitoring, and early breastfeeding initiation can improve the survival of infants with low birthweight (Deblew et al., 2014; Lawn et al., 2005; Onayade et al., 2006).

\section{The effect of family income on the risk of neonatal death through low birthweight}

This study showed that family income $\geq$ minimum regional wage (Rupiah) decreased the risk of low birthweight. 
Titaley et al. (2008), Sebayang et al. (2012), Kayode et al. (2014), and Demelash et al. (2015) explained that family income indirectly associated with low birthweight through the fulfillment of maternal nutritional intake during pregnancy.

\section{The effect of maternal education on the risk of neonatal death through infection}

This study showed that maternal education $\geq$ senior high school decreased the risk of infection and asphyxia (Lee et al., 2008). Prevention of infection in pregnant women can be done by providing information about infant care (Adetola et al., 2008).

Adetola et al. (2011) stated that mother with higher maternal education would be easier to recognize the sign and symptom of complication during pregnancy. Mother will choose the safe delivery service thus reducing the incidence of neonatal infection. Abdullah (2016) explained that low maternal education causes the mother to be less aware of signs of neonatal complications including the danger of infection during the first week of life.

10. The effect of maternal education on the risk of neonatal death through maternal employment status and family income

This study showed that family income increased with maternal education (Akinyemi et al, 2015). Education is an effort to achieve social and economic welfare of the family. According to Malqvist (2011) and Ankiyemi et al. (2015), that education is an effort to achieve family social and economic welfare. Maternal education has a strong association with their health status. They are able to apply health information, such as the need for food intake during pregnancy (Titaley et al., 2008). Singh (2013) found that mother who passed education $\geq 10$ years can decrease neonatal death.

\section{The effect of maternal employ- ment status on the risk of neonatal death through family income}

This study showed that working mother outside the house can increase family income. This finding is consistent with Titaley et al. (2008) and Malqvist (2011). They found that higher family income increased access to health service and maternal nutritional status during pregnancy.

This study concludes that the determinant of neonatal death was low birthweigth, asphyxia, prematurity, infection, maternal age $<20$ years or $\geq 35$ years, maternal education, maternal employment status, and family income.

\section{CONFLICT OF INTEREST}

None declared.

\section{REFERENCE}

Abdullah A, Hort K, Butu Y, Simpson L (2016). Risk factors associated with neonatal deaths: a matched casecontrol study in Indonesia. Global Health Action, 9. http://doi.org/10.3402/gha.v9.30445

Adetola AO, Olukemi OT, Adebola EO, Kike O (2011). Neonatal Mortality in an Urban Population in Ibadan, Nigeria. Pediatrics \& Neonatology. 52(5): 243250. https://doi.org/10.1016/j.pedneo.2011.06.001

Akinyemi JO, Bamgboye EA, Ayeni O (2015). Trends in neonatal morta-lity in nigeria and effects of bio demographic and maternal characteristics. BMC Pediatrics, 15, 36.

Aslam HM, Saleem S, Afzal R, Iqbal U, Saleem SM, Shaikh, MWA, Shahid N (2014). Risk factors of birth asphyxia. Italian Journal of Pediatrics, 40,94. http://doi.org/10.1186/s13052-0140094-2 
Baker PN, Campbell S, Lees C (2006). Obstetrics by ten teachers. 338 Euston road, London, NW1 3Bh: Hodder Arnold Publishers.

Berglund S, Pettersson H, Cnattingius S, Grunewald C (2010). How often is a low Apgar score the result of substandard care during labour? BJOG. 117: 968-78.

Chan GJ, Lee AC, Baqui AH, Tan J, Black RE (2013). Risk of early-onset neonatal infection with maternal infection or colonization: a global systematic review and meta-analysis. PLoS Medicine, 10(8): e1001502. http://doi.org/10.1371/journal.pmed.100150 2.

Debelew GT, Mesganaw FA, Alemayehu WY (2014). Determinants and Causes of Neonatal Mortality in Jimma Zone, Southwest Ethiopia: A Multilevel Analysis of Prospective Follow Up Study. Plos one journal.

Derakhshi B, Esmailnasab N, Ghaderi E, Hemmatpour S (2014). Risk Factor of preterm labor in the West of Iran: A case-control study. Iranian Journal of Public Health, 43(4): 499-506.

Demelash H, Motbainor A, Nigatu D, Gashaw K, Melese A (2015). Risk factors for low birth weight in Bale zone hospitals, South-East Ethiopia: a case-control study. BMC Pregnancy and Childbirth. 1-10. https://doi.org/10.1186/s12884-15-0677-y.

Ehrenstein V (2009). Association of Apgar scores with death and neurologic disability. Clin Epidemiol, 1: 45_53.

Fawole AO, Shah A, Tongo O, Dara K, ElLadan AM, Umezulike AC, et al. (2011). Determinants of perinatal mortality in Nigeria. Int $\mathrm{J}$ Gynecol Obstet. 114:37-42.
Flood K, Malone FD (2012). Prevention of preterm birth. Semin Fetal Neonatal Med, 17:58-63.

Friedman EM, Herd P (2010) Income, Education, and Inflammation: Differential Associations in a Natio-nal Probability Sample (The MIDUS Study). Psychosomatic medicine. 72(3): 290-300. doi:10.1097/PSY.obo13e31$81 \mathrm{cfe} 4 \mathrm{c} 2$.

Green CJ, Wilkinson JM (2012). Rencana Asuhan Keperawatan Maternal \& Bayi Baru Lahir. Terjemahan oleh Monica Ester, Ns.Nur Meity Sulistia Ayu, Yasmin Asih, Agus Sutarna. Jakarta: Buku Kedokteran EGC.

Halim A, Juan ED, Animesh B, Fazlur R, Sarah W, Nynke van den Broek2 (2016). When, Where, And Why Are Babies Dying? Neonatal Death Surveillance And Review In Bangladesh. Plos one. doi:10.1371/journal.pone.0159388

Kaboré R , Ivlabèhiré BM, Jean-Louis EK,Tiéba M, Seni K(2016). Factors Associated With Very Early Neonatal Mortality In Burkina Faso: A Matched Case-Control Study. International journal of gynecology and obstetrics 135 (2016) s93-s97

Kayode GA, Amoakoh-coleman M, Agyepong IA, Ansah E, Grobbee, DE, Klipstein-grobusch K (2015). Contex tual Risk Factors for Low Birth Weight: A Multilevel Analysis, 9(10): 1-8. https://doi.org/10.1371/journal.pone.0109333.

Kementerian Kesehatan Republik Indonesia (2015). Buku Profil Kesehatan Indonesia Tahun 2015.

Lawn JE, Cousens S, Zupan J (2005). 4 million neonatal deaths: When? Where? Why?. The Lancet. 365 (9462): 891-900. 
Lee AC, Mullany LC, Tielsch JM, Katz J, Khatry SK, Leclerq SC (2008). Risk factors for neonatal mortality due to birth asphyxia in Southern Nepal: A prospective, community-based cohort study. Pediatrics, 121(5), e1381-e1390. Http://doi.org/10.1542/peds.2007-1966.

Målqvist M (2011). Neonatal mortality: An invisible and marginalised trauma. Global health action.

Muchemi OM, Echoka E, Makokha A (2015). Factors associated with low birth weight among neonates born at Olkalou District Hospital, Central Region, Kenya. The Pan African Medical Journal, 20, 108. http://doi.org/10.11604/pamj.2015.20.108.4831

Nayeri F, Shariat M, Dalili H, Adam LB, Mehrjerdi FZ, Shakeri A (2012). Perinatal risk factors for neonatal asphyxia in Vali-e-Asr hospital, TehranIran. Iran J Reprod Med, 10(2): 137140.

Onayade A, Sule S, Elusiyan J (2006). Determinants of neonatal mortality at Westley Guild Hospital, Ilesa, Nigeria. Niger J Med. 15:271e6.

Pitsawong C, Panichkul P (2012). Risk factors associated with birth asphyxia in
Phramongkutklao Hospital. Thai J Obstet Gynaecol. 19(4): 165-171.

Prawirohardjo S (2012). Ilmu kebidanan. Jakarta: P.T Bina Pustaka Sarwono Prawirohardjo.

Rini SD, Nunik P (2014). Hubungan status kesehatan neonatal dengan kematian bayi. Jurnal Biometrika Dan Kependudukan, 3(1): 73-80.

Sebayang SK, Dibley MJ, Kelly PJ, Shankar AV Shankar AH (2012). Determinants of low birthweight, small for gestational age and preterm birth in Lombok, Indonesia: analyses of the birthweight cohort of the SUMMIT trial, 17(8): 938-950. https://doi.org/10.1111/j.1365-3156.2012.030-39x.

Singh A, Kumar A, Kumar A (2013). Determinants Of Neonatal Mortality In Rural India, 2007-2008. Peerj, 1, E75. Http://Doi.org/10.7717/Peerj.75

Titaley C, Michael JD, Kingsley AG, Christine LR, John HL (2008). Determinants of neonatal mortality in Indonesia. BMC Public Health, 8: 232.

United Nations Inter-Agency Group For Child Mortality Estimation (Un Igme) (2015). Level and trend in child mortality. Diunduh 19 Januari 2017. 